\section{Social justice as a factor in socio-economic preconditions effective process of economic transformation Ukraine}

\author{
Shavalyuk, Oleksandr - Popivniak, Roman \\ Lviv National Agrarian University, Ukraine \\ sh_alexandr@ukr.net
}

\section{SUMMARY}

The article deals with social justice as the main factor of social and economic prerequisites for effective transformation of the economy of Ukraine and basic ways of overcoming injustice in the social sphere of life.

Keywords: economic crisis, social justice, economic efficiency, competitiveness

\section{INTRODUCTION}

The main causes of deep economic crisis in Ukraine is the lack of a model transformation of the economy based on market principles that would meet the specifics of our society and the lack of a reliable system of economic security, which would contribute to creating self-sufficient, competitiveness, socially oriented economy and would ensure its protection internal and external destructive influences.

The main goal of Ukraine's strategy is ensuring that economic development, in which it was possible to create conditions for the development of socioeconomic interests of citizens, ensuring macroeconomic stabilization, storage integrity, and ensure that its economic independence.

\section{MAIN MATERIAL}

Reformist forces that implement socio-economic changes in our country, trying to convince the public that today continues the transition to a social market economy, however, remains unresolved key question that emerges as the most important for social development: ungrounded population differentiation in obtaining production results, the root of which is a pathological form of ownership of the means of production. Despite the availability of the overall social transformations for the normal functioning of the economic system, economic resources and needs of the population, the economic life of the country degrades. Deteriorating macroeconomic indicators continued impoverishment of the vast majority of citizens. This is evidenced by the uncertainty of the specific perspectives of Ukrainian society (Social Economy, 2005).

The transformation of the social structure of Ukrainian society has deep, solid character. Destroyed the old structure, the middle class, generally clear boundaries between classes, new social formations. Update a character and become global scale polarization of society. As the fastest, most intense began moving downward plan, the company was split into two parts: the upper strata, which are big profits and privileges and all other vulnerable and disadvantaged (Davydyuk, 2010).
As a result, the state finds itself in circumstances where the social support needs most of the population. The situation is complicated by the fact that the process of stratification itself is complex and controversial. Polarization intersects blurring boundaries, velocity structure transformation, and the slow emergence of new social formations. Most groups have a clearly defined form class is - class of similar marginal education. Vagueness, lack of social structure reduces the possibility of effective social control and implements adequate measures of social policy (Davydyuk, 2010).

Effective social policy directly affects not only the development of production, but also the transformation of socio-economic relations of society. This process of "human capital", provides nature of economic relations between the main actors of social production, brings to life a qualitatively new to the market economy phenomenon of corporate social responsibility, companies, entrepreneurs, transforming the system of interest and motivation to work.

In Ukraine, the principle of social equilibrium is realized through the establishment of rules of market behavior that takes into account social values, put the collective interest ahead of personal and main instrument such intervention should be a system of regulation of social and economic processes that ensure the effective use of these rules in the interest of the majority (Davydyuk, 2010).

In modern conditions, only the state can regulate the social development of society, as business is still poorly involved in the implementation of social policies, resolving social contradictions, maintain the required balance of strategic and tactical public interest, and sometimes acts contrary to those interests. The deepening social inequality leads to devastating consequences, since the economy can not function effectively or as productive or as consuming system (Davydyuk, 2010).

Consequently, modern social policy is doomed to fail without a fundamental transformation of the entire system of government, which is to be effective, balanced, and responsible to the people. However, the growth of the shadow economy, criminalization and corruption of power in Ukraine reached such proportions that threaten national security (Davydyuk, 2010).

Thus, at present the main trends in the transformation of the social structure of Ukrainian society include further deepening social inequalities in all indicators (economic, political and social) and the marginalization of a large part of the population that carries the growing tension in the society. On the one hand, social inequality is the result of prevailing in recent years, income distribution and access to economic, political, social resources, on the other - the result of government policy. Further 
development of stratification processes in Ukrainian society will depend on the speed of economic and political reform on changes in state ideology, which today replaced the interests of a narrow group of people (Davydyuk, 2010).

That is, at the present stage for Ukraine's economy even under favorable conditions, the development of innovative models of economic growth expected to move in the direction of the old industrialism, not transformational shift to post-industrial civilization, and therefore, the socialization of the economy, creates conditions for the development of spiritual and intellectual potential of the nation, with the increase his well-being, there is the problem of overcoming the economic crisis and transformational transition to a new civilization, which promptly sent the Western world, relying on basic Christian values: Truth, Truth, Mercy, Welfare, which became the basis of morality, culture and economic progress. And here in the first place, you can set a goal of a free society is the key to the false ways of Ukrainian society to a new dictatorship or renewal of a unitary centralized state with a combination of state economy and overly controlled state "market" (Social Economy, 2005).

\section{CONCLUSION}

So, in the formation and development of social relations and the social security system a significant place belongs to the state, not focused on the interests of the financial and industrial oligarchs, and the preservation of human capital, social capital development, support legislative and executive formation of such a social institution, which is the middle class that has become an active component of the productive forces of the country, with its inherent ability to self-organization, mobility in advancing their own interests and use this to civilized forms of pressure. Such structural forms function of middle-class society can be realized only if its size (almost 60\%) (Social Economy, 2005).

Thus, today in Ukraine improve social policy need not only the poor, which are all highly skilled workers and scientists, but also those that may be middle class. So, ignoring the principles of social justice, admitted in Ukraine requires an established joint activity of the legislative, executive, along with the involvement of all social forces on the basis of democratic norms, ensuring social balance in the society should contribute to a new quality of economic development (Social Economy, 2005).

\section{REFERENCES}

Davydyuk, O. (2010): Social policy in conditions of deepening social inequality in Ukraine . http://cpsr.org.ua/index.php?option=com content\&view $=$ article $\&$ id $=133: 2010-12-08-15-45-36 \&$ catid $=$ 29:2010-06-15-18-48-34\&Itemid=35.
Social Economy (2005): Belyajev, O. et al. (eds.) KNEU. 196. 